\title{
Pola Komunikasi Edukasi di Koperasi Unit Desa dan di Koperasi Pondok Pesantren (Studi di Provinsi Jawa Barat)
}

\author{
Wawan Lulus Setiawan \\ Institut Manajemen Koperasi Indonesia \\ wawanlulus@ikopin.ac.id
}

\begin{abstract}
ABSTRAK
Penelitian ini bertujuan mendeskripsikan perbedaan pola komunikasi edukasi di KUD dan di Kopontren di Jawa Barat. Penelitian dilakukan dengan pendekatan kualitatif. Hasil penelitian menunjukkan komunikasi edukasi di kopontren lebih kuat daripada komunikasi edukasi di KUD, karena proses komunikasi edukasi di pesantren telah merupakan paket program pendidikan di pesantren yang telah dibakukan dalam kurikulum pendidikan di pesantren. Dengan demikian, unsurunsur who says what to whom in which channel and in what effect serta lingkungan di pesantren telah dipaketkan dalam sebuah kurikulum komunikasi edukasi di pesantren.
\end{abstract}

Kata Kunci: Komunikasi-edukasi, KUD, Kopontren

\begin{abstract}
The purpose of this research is to describe the differences between the pattern of educational communication in the Village Unit Cooperatives (KUDs) and that in the Traditional Iskamic Boarding School Cooperatives (Kopontrens) in West Java Province, Indonesia. The research was carried out with qualitative approach on 12 KUDs and 12 Kopontrrens in West Java Province, Indonesia. The idea of research was based on the International and Indonesian Cooperative Principles which obliges the cooperatives to arrange cooperative education program for the cooperative's members and based on the facts of cultural background differences between KUDs and Kopontrens. The result of the research indicated that educational communication in the Kopontrens is stronger than that in the KUDs because the process of educational communication process in the Kopontrens has become a standardized educational program, so that the elements of communication process consisting of "who says what to whom in which channel, in what effect and environtment" has become a package of the educational communication curriculum in Kopontrens. This could explain why the members' participation in the Kopontrens is better than that in the KUDs. This result of the study could give social and policy implication for developing method of members educatin in the KUDs in Indonesia.
\end{abstract}

Keywords: Komunikasi-edukasi, KUD, Kopontren

\section{PENDAHULUAN}

\section{Latar Belakang Penelitian}

Hingga Tahun 2010, 51.2 persen penduduk Indonesia, masih boleh dikatakan mayoritas, tinggal di perdesaan (Sensus Penduduk tahun 2020) ${ }^{1}$. Dari segi mata pencaharian, 46.26 persen penduduk bermata pencaharian sebagai petani kecil atau petani gurem dengan kepemilikan lahan kurang dari 0.5 hektar, sehingga tidak ekonomis (Kantor Menko Perekonomian, 2008). Mayoritas penduduk miskin, yaitu 63.3 persen dari total penduduk miskin di Indonesia sejumlah 27.55 juta

\section{1}

https://www.bps.go.id/statictable/2014/02/18/1276/persen tase-penduduk-daerah-perkotaan-hasil-proyeksipenduduk-menurut-provinsi-2015---2035.html orang, adalah penduduk perdesaan ${ }^{2}$. Oleh karena itu, peran yang diharapkan dari koperasi untuk mengembangkan perekonomian masyarakat perdesaan tertuju kepada Koperasi Unit Desa (KUD). Namun, perkembangan Koperasi Unit Desa saat ini pun tidak menggembirakan. Pada kasus Jawa Barat, misalnya, dari 486 KUD yang tercatat, ada 170 KUD tidak aktif ${ }^{3}$. Kondisi ini tidak jauh berbeda dengan kondisi pada tahun 2009, dari 486 KUD yang tercatat pada Pusat Koperasi Unit Desa Jawa Barat tahun 2009, hanya 200 KUD (41.3 persen) yang masih aktif melaksanakan Rapat Anggota Tahunan.

https://www.bps.go.id/website/materi_ind/materiBrsInd20210215114827.pdf

${ }^{3}$ http://induk-kud.com/kud-dinilai-sudah-saatnyaberganti-kemasan/ 
Dalam situasi perkembangan koperasi perdesaan seperti ini, ada harapan yang tertuju kepada Koperasi Pondok Pesantren (Kopontren) sebagai pelengkap terhadap kekurangan dan keterbatasan yang dihadapi KUD dalam perannya sebagai lembaga ekonomi masyarakat perdesaan. Hal ini diungkapkan oleh Herman Soewardi (1995:5) bahwa: "Kopontren bisa dijadikan juru selamat bagi perbaikan krisis ekonomi pada tingkat mikro di Indonesia".

Memperkuat pandangan tentang peran kopontren, Eva Nur Arovah (2003) dari hasil penelitiannya tentang Pesantren dan Pasar di Pedesaan Cirebon. Agama dan Ekonomi di Tegalgubug Pada abad $\mathrm{XX}$, menyimpulkan bahwa para pemimpin agama itu adalah pembaharu di bidang ekonomi. Pesantren telah merangsang perubahan sosial dan telah membekali pengikutnya motivasi kuat untuk pembangunan ekonomi.

Namun demikian, di lingkungan perdesaan Jawa Barat, ada beberapa KUD dan Kopontren yang telah menunjukkan perannya dengan sangat baik dalam pengembangan ekonomi masyarakat, misalnya KUD Bayongbong di Kabupaten Garut, Koperasi Peternak Sapi Bandung Utara, KUD Trisula di Kabupaten Majalengka, Kopontren Al Itifak di Ciwidey, Koperasi Pondok Pesantren Daarut Tauhid Bandung, Koperasi Pondok Pesantren Fathyah Tasikmalaya, dan lain-lain. Keberhasilan koperasi-koperasi ini antara lain dikarenakan memiliki pendekatan komunikasi yang baik yang dilakukan oleh pengurus koperasi kepada para karyawan dan anggotanya, yaitu komunikasi yang didasari oleh semangat demokrasi dan edukasi,

Berdasarkan uraian latar belakang di atas, maka fokus masalah penelitian terarah pada masyarakat koperasi, yaitu pada KUD dan Kopontren di Provinsi Jawa Barat yang mencakup empat wilayah (I, II, III, dan IV) Jawa Barat. Sehubungan dengan fokus masalah penelitian tersebut, maka problem statement (rumusan masalah) dalam penelitian ini adalah "bagaimana perbedaan komunikasi edukasi antara KUD dan Kopontren" Masalah penelitian tersebut dibahas menurut kajian Ilmu Komunikasi. Untuk menjawab masalah penelitian itu dilakukan dengan pendekatan kualitatif.

Bertitiktolak dari latar belakang masalah tersebut, penulis melakukan penelitian tentang "Pola Komunikasi Edukasi di KUD dan di Kopontren (Suatu Studi Pada KUD dan Kopontren di Jawa Barat)". Maksud penelitian ini adalah untuk mendeskripsikan perbedaan pola komunikasi edukasi di KUD dan di Kopontren. Data yang digunakan berupa data kualitatif yang diperoleh dari penelitian di 12 koperasi di Jawa Barat, terdiri dari 6 KUD dan 6 kopontren selama kurun waktu 2009 - 2011. Data diperoleh dari narasumbernarasumber yang berasal dari kalangan pengurus dan anggota KUD dan kopontren yang dijadikan subjek penelitian, menggunakan teknik wawancara mendalam dan FGD (focus group discussion). Pemilihan KUD dan kopontren diambil pada strata ekosistem pegunungan, dataran tinggi dan pantai secara stratified random sampling, sedangkan pemilihan narasumber dilakukan secara purposive berdasarkan pertimbangan penguasaan terhadap data yang hendak dikumpulkan.

\section{Pendekatan Masalah}

Berbagai tipe riset komunikasi pada umumnya dapat terjawab oleh rumusan Laswell (dalam Mulyana, 2001:147). Proses komunikasi dengan paradigma rumusan Laswell akan menciptakan struktur dan efek. Rumusan yang dikemukakannya adalah: "who says what in which channel to whom with what effect". Penjelasan dari rumusan ini adalah sebagai berikut:

- Who adalah komunikator atau siapa yang mengataknnya/berbicara.

- Says what: adalah apa yang dikatakannya/isi pesan

- In which channel adalah media apa yang dipergunakannya.

- To whom adalah receiver/siapa yang akan menerimanya.

- With what effect adalah efek yang ditimbulkan dari proses komunikasi yang berjalan.

Rumusan ini kemudian dikembangkan oleh Braddock (dalam Dewi, 2008:41) yang menyatakan ada pertimbangan lain dalam proses komunikasi selain lima point di atas. Braddock menambahkan dua point dalam proses komunikasi, yaitu (1) lingkungan di sekitar proses komunikasi, dan (2) maksud dari penyampaian pesan. Dua unsur ini melengkapi rumusan Laswell untuk menjawab riset komunikasi organisasi, karena komunikasi berproses dalam suatu lingkungan yang terstruktur. Dalam kajian ini, lingkungan yang terstruktur yang dimaksud adalah KUD dan Kopontren. 


\section{BRADDOCK}

Braddock memperluas formula Lasswell dengan mengemukakan Bahwa komunikasi berlangsung dalam situasi tertentu dengan Tujuan tertentu pula.

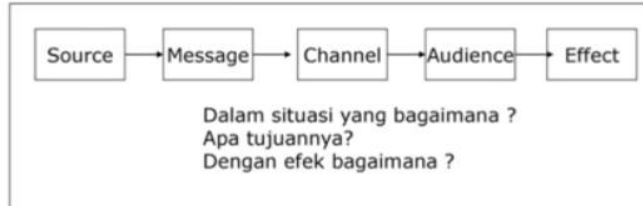

\section{Gambar 1. Komunikasi Braddock}

Rumusan Laswell yang dilengkapi oleh Braddock di atas juga tepat untuk menjela skan proses komunikasi edukasi di koperasi. Selain menggambarkan proses komunikasi, juga dengan model ini dapat mengungkapkan maksud komunikasi. Komunikasi edukasi dimaksudkan untuk mendidik khalayak. Mendidik berarti memberikan suatu ide kepada khalayak apa sesungguhnya, di atas fakta-fakta, pendapat, dan pengalaman yang dapat dipertanggungjawabkan dan segi kebenarannya, dengan disengaja teratur dan terencana, dengan tujuan mengubah tingkah laku manusia ke arah yang diinginkan (Arifin, 1984:77).

Komunikasi edukasi di koperasi sering disebut sebagai pendidikan perkoperasian. Tentang pentingnya pendidikan perkoperasian ini, khususnya bagi anggota, Book (1994:41) menyatakan bahwa untuk memperbaiki pelayanan koperasi, untuk dapat bersaing dengan badan-badan usaha lain, maka anggota harus mengikuti pendidikan mengenai masalah-masalah praktis, pengetahuan dan pengertian tentang, metode koperasi serta mehami perubahan-perubahan yang terjadi di lingkungan koperasi.

\section{Metode Penelitian}

Penelitian ini dilakukan dengan metode deskriptif kualitatif, dimaksudkan untuk mengungkapkan masalah, keadaan atau peristiwa yang terkait dengan fenomena komunikasi sebagaimana adanya kemudian mengungkapkan makna yang ada di balik fenomena yang sedang dipelajari. Subjek dalam penelitian ini adalah para pengurus, pengawas, karyawan, dan anggota pada KUD dan Kopontren di Jawa Barat yang menjadi sampel penelitian.

Objek penelitian (materi atau fenomena yang diteliti) adalah komunikasi edukasi di KUD dan di
Kopontren berdasarkan unsure who, says what, in which channel, in what effect, dan lingkungan. Pedoman wawancara dan observasi digunakan sebagai informasi yang pokok.

Penelitian dilakukan pada enam KUD dan enam Kopontren di Jawa Barat yang diambil pada strata ekosistem pegunungan, dataran tinggi dan pantai. Hal ini sebagaimana tertera pada tabel berikut:

Tabel 1. Koperasi yang Dijadikan Sampel Penelitian

\begin{tabular}{|c|c|c|c|c|}
\hline \multirow{2}{*}{$\begin{array}{c}\text { Stara } \\
\text { Ekosistem } \\
\text { Jawa Barat }\end{array}$} & \multirow{2}{*}{ Kabupaten } & \multirow{2}{*}{$\begin{array}{c}\text { Wilayah } \\
\text { Jabar }\end{array}$} & \multicolumn{2}{|c|}{$\begin{array}{l}\text { Nama-Nama Koperasi Beserta Alamat Jenis } \\
\text { Koperasi } \\
\end{array}$} \\
\hline & & & KUD & Kopontren \\
\hline PegununganDekat Kota & Sukabumi & Bogor & KUD Makmur & Samsul ulum Kec.Cisaa \\
\hline Pegunung Jauh Ke Kota & Bandung & Priangan & $\begin{array}{l}\text { KUD Pasijambu } \\
\text { Kec. Pasinjambu }\end{array}$ & $\begin{array}{l}\text { Al Ittifak } \\
\text { Kec Ciridey }\end{array}$ \\
\hline $\begin{array}{l}\text { Dataran Tinggi Dekat } \\
\text { Kota }\end{array}$ & Purvakarta & Purwasuka & $\begin{array}{l}\text { KUD Wama sai Kec. } \\
\text { Purwakarta }\end{array}$ & $\begin{array}{l}\text { Al-Muhajinin } \\
\text { Kec.Punvakarta }\end{array}$ \\
\hline $\begin{array}{l}\text { Dataran Tinggi JauhKe } \\
\text { Kota }\end{array}$ & Ganut & Priangan & KUD Bayongbong & $\begin{array}{l}\text { Miftahul ulum } \\
\text { Kecamatan } \\
\text { Karang pawitan }\end{array}$ \\
\hline PantaiDekatKota & Indramayu & Cirebon & KUD HarapanMulya & HidayatulMuttaq̣in \\
\hline PantaiJauhke Kota & Karawang & Purvasuka & KUD Warga Bakti & $\begin{array}{l}\text { Goyatuljihad } \\
\text { Kec Talagasari }\end{array}$ \\
\hline
\end{tabular}

\section{Hasil Penelitian}

Komunikasi edukasi di KUD dan kopontren dibahas dengan menggunakan kombinasi rumusan komunikasi dari Laswell (yaitu Who says what in which channel to whom and in what effect) serta Braddock (yaitu lingkungan dan maksud dari penyampaian pesan).

\section{1) Komunikasi Edukasi di KUD}

a) who:

Komunikasi edukasi di KUD pada umumnya dilakukan oleh pihak pengurus. Di lihat dari pengalaman kerjanya kompetensi para pengurus KUD dalam berkomunikasi tidak diragukan lagi. Rata-rata para pengurus KUD telah memiliki pengalaman kerja atau berorganisasi yang cukup mapan, baik pengalaman menjadi pengurus koperasi yang rata-rata sudah lebih dari 5 tahun, ditambah dengan pengalaman berorganisasi di masyarakat dalam wadah organisasi kemasyarakatan ataupun pengalamannya sebagai tokoh masyarakat ataupun sebagai Kepala Desa. Kemampuan mereka dalam meyakinkan khalayak dalam berkomunikasi sangat luar biasa. Karena kemampuannya itulah mereka terpilih sebagai pengurus di KUD. Namun, dari pengurus KUD rata-rata belum memiliki pengalaman dalam bidang pekerjaan sebagai pendidik, baik itu di lingkungan pendidikan formal (sebagai guru), ataupun di lingkungan pendidikan non-formal (misalnya sebagai ustadz atau kyai di pesanrten), sehingga pengalaman mereka dalam komunikasi edukasi masih sangat kurang. 


\section{b) Says what:}

Pesan komunikasi yang disampaikan saat komunikasi edukasi antara pengurus dan anggota KUD pada umumnya menyangkut pelaksanaan hak dan kewajiban anggota di koperasi, yaitu hak-hak anggota dalam kedudukanya sebagai pemilik koperasi (menghadiri rapat anggota, turut mengambil keputusan di rapat anggota dengan cara memberikan hak suaranya), dan hak anggota sebagai pengguna jasa koperasi (menggunakan layanan koperasi) agar usaha koperasi berkembang, serta kewajibannya anggota dalam kedudukannya sebagai pemilik koperasi (dengan pembayaran simpanan wajib), dan kewajibannya sebagai pengguna jasa koperasi (dengan pembayaran cicilan kredit tepat waktu) agar usaha koperasi daspat berjalan lancar.

\section{c) to whom}

Kelompok sasaran dalam komunikasi edukasi di KUD adalah para anggota KUD. Mereka adalah masyarakat desa dengan mata pencaharian yang sangat bervariasi. Namun mayoritas anggota bermatapencaharian sebagai petani. Tingkat pendidikan formal mereka rata-rata relatif masih rendah (rata-rata SD dan SMP tidak tamat). Pengalaman berorganisasi dalam masyarakat ratarata masih minim.

Latar belakang tersebut nampaknya mempengaruhi cara mereka berkomunikasi dan menangkap pesan komunikasi. Mereka berkomunikasi cenderung apa adanya. Namun, mereka pada umumnya kurang berani dalam berbicara dalam forum, jadi mereka akan mempercayakana pesannya kepada "jago"nya. Di sisi lain mereka jadi terkuasai oleh beberapa orang yang memiliki kemampuan komunikasi menonjol di antara mereka. Jadi, suara anggota koperasi di forum itu seringkali tidak menggambarkan suara anggota mayoritas koperasi, melainkan suara dari beberapa orang yang memiliki kemampuan komunikasi yang menonjol, dan anggota yang lain terpengaruh untuk mengikuti suara mereka.

\section{d) in which channel:}

Komunikasi edukasi di KUD pada umumnya dilakukan oleh pihak pengurus, kecuali pada beberapa KUD yang melaksanakan unit usaha sapi perah (seperti KUD Bayongbong, KUD Makmur, dan KUD Pasirjambu), komunikasi edukasi selain oleh pengurus KUD juga dilakukan oleh petugas khusus kesehatan hewan yang dimaksudkan untuk memberikan bimbingan teknis tentang penanganan kesehatan sapi perah dan penganan susu sapi agar kualitas susu yang dihasilkan para anggota KUD memenuhi syarat yang ditetapkan oleh Gabungan Koperasi Susu Indonesia (GKSI).
Rapat Anggota Tahunan dilaksanakan di sebuah ruangan yang menampung kurang lebih 200 orang. Bagi KUD yang memiliki anggota dengan jumlah yang besar, biasanya rapat anggota dilaksanakan dalam dua tahap. Tahap pertama dilaksanakan di kelompok anggota yang biasa disebut pra-RAT, tahap kedua dilaksanakan RAT di KUD yang dihadiri oleh perwakilan kelompok anggota.

Komunikasi berlangsung secara langsung tatapmuka, dengan menggunakan media pengeras suara, sedangkan pesan komunikasi yang berupa bahan rapat disediakan dan dibagikan kepada para anggota dalam bentuk laporan tahunan koperasi. Dengan komunikasi langsung tatap-muka ini, maka proses komunikasi edukasi berlangsung lebih efektif, karena hal-hal yang menjadi kesalahpahaman dapat segera dijelaskan oleh pihak pengurus, dan umpan balik pun dapat segera diperoleh pihak pengurus.

Para peserta rapat anggota yang merupakan perwakilan kelompok diharuskan menyampaikan keputusan-keputusan rapat kepada para anggota di kelompoknya. Di sini lah seringkali terjadi bias antara pesan yang disampaikan atau dimusyawarahkan dan diputuskan di RAT dengan pesan yang sampai kepada anggota. Maka, seringkali persoalan yang sudah dibahas di RAT saat ini kemudian dipertanyakan kembali oleh anggota pada RAT berikutnya.

\section{e) with what effect (maksud):}

Komunikasi edukasi di KUD dan di kopontren sebenarnya merupakan kewajiban yang harus dilakukan oleh pihak pengurus, karena hal ini digariskan oleh prinsip koperasi yaitu tentang pendidikan perkoperasian. Komunikasi edukasi merupakan salah satu faktor penting dalam gerakan koperasi yang dimaksudkan untuk untuk meningkatkan pemahaman dan kompetensi seluruh warga koperasi yang mencakup pengurus, karyawan dan anggota koperasi. Kompetensi yang dimaksud mencakup sikap yang positif terhadap koperasi, pengetahuan dan keterampilan yang memadai untuk mengelola dan berpartisipasi di koperasi.

Komunikasi edukasi yang dilakukan oleh pengurus koperasi kepada para anggota sering disebut pula sebagai program pendidikan anggota. Pendidikan anggota ini sangat menentukan bagi kelancaran organisasi dan usaha koperasi, agar anggota dapat memahami dan melaksanakan hak dan kewajibannya di koperasi. Pemahaman dan keyakinan anggota terhadap manfaat koperasi juga merupakan salah satu output dari pendidikan anggota. Pada gilirannya pendidikan anggota juga mendukung kepada pelaksanakanan prinsip sukarela dalam keanggotaan koperasi, karena asas sukarela juga dapat dimaknakan bahwa seseorang pengusaha memutuskan untuk bergabung dengan 
pengusaha lain dan mendirikan koperasi yaitu karena diyakini bahwa dengan menyelengarakan kegiatan kolektif maka akan didapat dampak sinergy (synergy effect) atau manfaat ekonomi skala besar (economies of large scale).

\section{f) lingkungan:}

KUD berada dalam lingkungan masyarakat pedesaan. Proses komunikasi edukasi di KUD pun dipengaruhi oleh nilai-nilai budaya yang berlaku pada masyarakat pedesaan setempat. Salah satu nilaya budaya lokal yang nampak dalam proses komunikasi edukasi di KUD adalah berlakunya struktur sosial masyarakat dalam proses komunikasi. Dalam masyarakat desa terdapat pelapisan sosial (atas, menengah dan bawah), pelapisan sosial ini mencerminkan pengaruh dari warga masyarakat yang berada di lapisan atas kepada warga masyarakat yang berada di lapisan bawah. Dengan demikian, struktur sosial kemudian menjadi struktur "kekuasaan" (struktur pengaruh) dalam proses komunikasi edukasi di masyarakat pedesaan.

Struktur pengaruh pada anggota KUD di masyarakat desa dapat menjadi suatu potensi positif, karena struktur ini dapat dimanfaatkan oleh pihak pengurus KUD untuk mendifusikan pesanpesan edukasi perkoperasian kepada para anggota melalui anggota-anggota KUD yang memiliki pengaruh di kalangan anggota lain atau di kalangan masyarakat. Namun, di sisi lain, kehadiran struktur pengaruh ini dapat juga berdampak negatif dalam proses komunikasi edukasi, karena suara anggota KUD pada kenyataannya dikuasai oleh para anggota KUD yang memiliki pengaruh, dan pada kenyataannya mereka adalah kelompok minoritas dari segi jumlah dibanding jumlah keseluruhan anggota KUD.

\section{2) Komunikasi Edukasi di Kopontren.}

\section{a) who:}

Komunikasi edukasi di kopontren kepada para anggota dilakukan oleh pihak pengurus. Di lingkungan kopontren, pengurus koperasi adalah para pengasuh (ustadz) di pesantren tersebut, sedangkan para anggota koperasi adalah warga pesantren yang mencakup para santri dan para pengasuh di pesantren tersebut. Dengan demikian, kemampuan para pengurus kopontren dalam melakukan komunikasi edukasi dengan para anggota, baik dari aspek pesan komunikasi maupun dari aspek teknik komunikasi, tidak diragukan lagi.

Kemampuan para kyai/ustadz di pesantren dalam menyampaikan pesan komunikasi kepada para santri atau jamaah sudah sangat terasah. Penguasaannnya terhadap materi pengajaran Agama Islam yang sangat memadai disertai dengan penguasaan metode dakwah, maka paduannya adalah kompetensi dakwah yang menakjubkan. Salah satu kemampuan para pengasuh di pesantren adalah

kemampuannya dalam dispersi dan konvergensi ${ }^{4}$ pesan. Dispersi pesan artinya sebuah pesan diuraikan berdasarkan unsur, ciri atau sifatnya sehingga menjadi lebih jelas dan mudah dapahami oleh para santri atau jamaah. Sedangkan konvergensi pesan artinya dari pesan-pesan yang bersifat majemuk dan umum kemudian dikerucutkan menjadi sebuah intisari pesan.

Sebagai contoh dispersi pesan adalah penjelasan KH Fuad tentang penjabaran dari makna kholifah di muka bumi bagi para santrinya di lingkungan pondok pesantren Al Ittifak.

(1) Habluminallah: diungkapkan dalam empat kata yaitu shalat awal waktu berjamaah di mesjid, (2) Habluminannas: rukun umat seagama dan umat beragama, artinya kita harus menjalin hubungan baik dengan sesama lintas agama, lintas mazhab dan lintas sektoral, dan (3) hubungan dengan alam, semua alam ada guna/faedahnya, walaupun sampah sekalipun bisa dimanfaatkan sebagai pupuk kompos. Penggunaan tanah harus sesuai, tanah datar kebonan, tanah legok balongan, tanah gawir kaian (tanah datar digunakan untuk kebun, tanah cerukan digunakan untuk kolam, tanah lereng digunakan untuk tanaman kayu $)^{5}$.

\section{b) Says what:}

Di lingkungan pesantren, kopontren dapat merupakan laboratorium/tempat praktek para santri untuk menerapkan ajaran di pesantren mengenai ilmu berwirausaha dan berkoperasi sesuai dengan ajaran Islam, selain dari sebagai wadah/lembaga ekonomi yang dapat membantu warga pesantren memenuhi kebutuhan-kebutuhan ekonominya. Oleh karena itu, komunikasi edukasi dalam konteks penyampaian nilai-nilai dasar perkoperasian dan kewirausahaan di lingkungan kopontren sudah bagian dari program pendidikan di pesantren.

Islam telah menggariskan prinsip-prinsip berwirausaha dan berkoperasi (bekerjasama dalam bisnis), baik dalam ayat Al Qur'an ataupun dalam Al Hadits. Ada 23 prinsip tentang etos kerja (berwirausaha) dan berkoperasi yang terdapat dalam al-Qur'an dan al-Hadits Prinsip-prinsip ini juga

\footnotetext{
${ }^{4}$ Istilah dispersi dan konvergensi diambil penulis dari teori fisika tentang perambatan cahaya . Proses disversi cahaya terjadi jika cahaya dirambatkan melalui sebuah prisma corpuscular. Cahaya putih oleh prisma dapat didispersikan/diuraikan menjadi cahaya-cahaya yang berwarna-warni. Sedangkan proses konvergensi cahaya terjadi pada saat cahaya putih dirambatkan melalui lensa cembung, maka cahaya akan dipancarkan memusat sehingga menjadi lebih kuat intensitasnya.

${ }^{5}$ Wawancara dengan KH Fuad di Kopontren Al Ittifak tanggal 5 April 2011
} 
menjadi bagian dari ajaran yang disampaikan di pesantren. Prinsip-prinsip tersebut adalah: (1) keseimbangan tujuan sukses di dunia dan di akhirat, (2) jual-beli halal, riba haram, (3) kerja adalah ibadah; (4) tanggung jawab dalam usaha; (5) pola hidup sederhana; (6) cinta kasih sesama; (7) kejujuran dalam berusaha; (8) amanah dalam berusaha; (9) ketekunan dalam berusaha; (10) kerja keras dalam berusaha; (11) perencanaan dalam berusaha; (12) inovatif dan progresif dalam berusaha; (13) mencontoh dan memberi contoh dalam berusaha; (14) bekerjasama dalam berusaha; (15) berpandangan ke depan dalam berusaha; (16) senantiasa meningkatkan ilmu; (17) semangat berusaha (bersaing); (18) efektifitas dan efisiensi waktu; (19) tahan uji dalam berusaha; (20) kepemimpinan dalam berusaha; (21) semangat wiraswasta; (22) pembukuan dalam berusaha; dan (23) profesionalisme dalam berusaha. ${ }^{6}$

\section{c) to whom}

Kelompok sasaran dalam kemunikasi edukasi di lingkungan pesantren adalah para santri atau siswa. Mereka termasuk golongan terpelajar. Latar belakang tersebut mempengaruhi cara mereka berkomunikasi dan menangkap pesan komunikasi. Komunikasi di antara pengasuh dan para santri berlangsung dalam hubungan guru-murid, yang dicirikan menonjol dengan suasana tata-krama dan ketaatan pada guru. Namun, kekuatan pesan komunikasi edukasi di pesantren adalah pada keteladanan dari para pengasuh pesantren sendiri.

\section{d) in which channel:}

Komunikasi edukasi di pesantren pada umumnya dilakukan oleh pihak pengasuh pesantren secara langsung tatap muka kepada para santri/siswa. Sedangkan pesan komunikasi disajikan dalam bahan ajar (modul) yang kemudian dijelaskan lebih rinci dengan media papan tulis. Dengan komunikasi langsung tatap-muka ini, maka proses komunikasi edukasi berlangsung lebih efektif, karena hal-hal yang menjadi kesalahpahaman dapat segera

\footnotetext{
${ }^{6}$ Referensi utama dari Tajul Arifin (2004) dan Koko Iskandar (2007) yang merinci 21 prinsip yaitu: (1) kerja adalah ibadah; (2) tanggung jawab dan berusaha; (3) pola hidup sederhana; (4) cinta kasih sesama; (5) kejujuran dalam berusaha; (6) amanah dalam berusaha; (7) ketekunan dalam berusaha; (8) kerja keras dalam berusaha; (9) perencanaan dalam berusaha; (10) inovatif dalam berusaha; (11) mencontoh dalam berusaha; (12) bekerjasama dalam berusaha; (13) berpandangan jauh dalam berusaha; (14) menjaga kualitas dalam berusaha; (15) semangat dalam berusaha; (16) efektivitas dalam berusaha; (17) tahan uji dalam berusaha; (18) kepemimpinan dalam berusaha; (19) wiraswasta dalam berusaha; (20) pembukuan dalam berusaha; dan (21) profesionalisme dalam berusaha. KH Fuad dari Kopontren Al Ittifaq dalam wawancara dengan penulis pada tanggal 5 April 2011 memberikan masukan dan revisi menjadi 23 prinsip sebagaimana dipaparkan pada teks.
}

dijelaskan oleh pihak pengasuh, dan umpan balik pun dapat segera diperoleh pihak pengasuh.

\section{e) with what effect (maksud):}

Ada dua efek/maksud yang diharapkan dari komunikasi edukasi yang berlangsung di lingkungan pesantren pada umumnya dan lingkungan kopontren pada khususnya. Efek yang pertama adalah efek jangka pendek, yaitu efek yang diharapkan nampak selama santri/siswa masih aktif menjadi anggota kopontren, dan efek yang kedua adalah efek jangka panjang, yaitu efek yang diharapkan nampak pada saat santri/siswa lulus dari pesantren.

Secara jangka pendek, komunikasi edukasi di kopontren sebenarnya merupakan kewajiban yang harus dilakukan oleh pihak pengurus, karena hal ini digariskan oleh prinsip koperasi yaitu tentang pendidikan perkoperasian. Komunikasi edukasi merupakan salah satu faktor penting dalam gerakan koperasi yang dimaksudkan untuk untuk meningkatkan pemahaman dan kompetensi seluruh warga koperasi yang mencakup pengurus, karyawan dan anggota koperasi. Kompetensi yang dimaksud mencakup sikap yang positif terhadap koperasi, pengetahuan dan keterampilan yang memadai untuk mengelola dan berpartisipasi di koperasi.

Secara jangka panjang, komunikasi edukasi di kopontren diharapkan dapat menanamkan prinsipprinsip/nilai berkoperasi dan berwirausaha pada para santri/siswa, sehingga pada saat mereka lulus dari pesantren, mereka dapat menerapkan ajaran yang telah diterimanya selama di pesantren tentang nilai-nilai tersebut dalam kehidupannya di masyarakat. Mereka diharapkan dapat mencari nafkah dengan cara berwirausaha, bahkan lebih dari itu mereka diharapkan dapat mengembangkan koperasi di masyarakat.

Dalam bahasa pesantren, maksud komunikasi edukasi di pesantren adalah agar para santri "bisa ngaji dan ngejo", artinya agar para santri dapat memiliki ilmu agama dan memiliki ilmu untuk mencari nafkah sehingga mereka dapat berusaha secara mandiri.

\section{f) Lingkungan.}

Kopontren berada dalam lingkungan pesantren. Proses komunikasi edukasi di kopontren pun dipengaruhi oleh nilai-nilai tradisi yang berlaku pada masyarakat pesantren. Salah satu nilai tradisi yang nampak dalam proses komunikasi edukasi di kopontren adalah berlakunya hubungan (struktur sosial) kyai/pengasuh - santri/siswa dalam proses komunikasi. Dalam hubungan ini komunikasi yang

${ }^{7}$ ibid 
nampak dicirikan dengan suasana ketaatan dan sikap hormat dari santri/siswa kepada para pengasuh/kyai. Nilai-nilai tradisi dan masyarakat di pesantren memperkuat proses sosialisasi nilai-nilai dari pesan komunikasi edukasi dari para pengasuh kepada para santri. Proses kontrol sosial berlangsung dengan sangat kuat, baik dari para pengasuh kepada para santri maupun di antara para santri/siswa sendiri.

Lingkungan pesantren adalah lingkungan lembaga pendidikan. Komunikasi edukasi yang diselenggarakan pun merupakan bagian dari program pendidikan (kurikulum) di pesantren. Dengan demikian proses komunikasi edukasi di pesantren adalah proses komunikasi edukasi yang terencana. Ini sesuai dengan pendapat dari Arifin (1984 : 77) bahwa komunikasi edukasi dimaksudkan untuk mendidik khalayak dengan disengaja, teratur dan terencana, dengan tujuan mengubah tingkah laku manusia ke arah yang diinginkan (Arifin, 1984 : 77).

\section{3) Perbedaan Komunikasi Edukasi di KUD dan di Kopontren.}

Berdasarkan uraian tentang komunikasi edukasi di KUD dan di kopontren di atas dengan menggunakan struktur pola komunikasi Laswell dan Braddock, dapat disimpulkan bahwa komunikasi edukasi di kopontren lebih kuat daripada komunikasi edukasi di KUD. Kesimpulan ini berdasarkan kondisi sebagai berikut:

a. who: para pangasuh di pesantren/kopontren lebih memiliki kompetensi dalam penguasaan materi/pesan komunikasi dan metode komunikasi edukasi, karena latar belakang pendidikan mereka sangat memadai dalam bidang pendidikan Agama Islam.

b. Says what: materi/pesan komunikasi edukasi di kopontren lebih kuat dibanding di KUD, karena pesan komunikasi edukasi di pesantren telah merupakan kurikulum baku di pesantren.

c. To whom: kelompok sasaran komunikasi edukasi di pesantren adalah para santri/siswa. Mereka adalah orang terpelajar yang sikap mentalnya telah siap untuk menerima pesan komunikasi edukasi dari para pengasuh pesantren.

d. Effect: maksud komunikasi edukasi di kopontren/pesantren memiliki dua jangkauan, yaitu maksud jangka pendek dan maksud jangka panjang. Dalam jangka pendek pesan komunikasi edukasi dapat diterapkan dalam praktek berkoperasi di kopontren yang merupakan bagian dari program pendidikan pesantren, dan maksud jangka panjang adalah agar pesan komunikasi edukasi tersebut dapat diterapkan oleh para santri pada saat mereka telah hidup secara mandiri di masyarakat.

e. Lingkungan: lingkungan pesantren adalah lingkungan lembaga pendidikan. Nilai-nilai tradisi dan masyarakat di pesantren memperkuat proses sosialisasi nilai-nilai dari pesan komunikasi edukasi dari para pengasuh kepada para santri. Proses kontrol sosial berlangsung dengan sangat kuat, baik dari para pengasuh kepada para santri maupun di antara para santri/siswa sendiri.

\section{SIMPULAN}

Komunikasi edukasi di Kopontren lebih kuat daripada komunikasi edukasi di KUD, karena proses komunikasi edukasi di pesantren telah merupakan paket program pendidikan di pesantren yang telah dibakukan dalam kurikulum pendidikan di pesantren.. Dengan demikian, unsur-unsur who says what to whom in which channel and in what effect serta lingkungan di pesantren telah dipaketkan dalam sebuah kurikulum komunikasi edukasi di pesantren.

\section{DAFTAR PUSTAKA}

Arifin. Anwar, 1984. Strategi Komunikasi. Cetakan Kedua. Bandung : Penerbit Armico.

Arifin, Tajul. 2004. Pengaruh Agama Islam dan Budaya Terhadap Prestasi Ekonomi. Disertasi Unpad. Bandung

Book, Sven Ake. 1992. Nilai-Nilai Koperasi Dalam Era Globalisasi. (Terjemahan Djabaruddin Djohar). Jakarta : Penerbit KJAN.

Dewi, Rosmala. 2008. Pengaruh Komunikasi Organisasi Melalui Motivasi Terhadap Produktivitas Kerja Pada PT KERETA API (Persero). Disertasi. Bandung : PPS Unpad.

https://www.bps.go.id/statictable/2014/02/18/1276/ persentase-penduduk-daerah-perkotaan-hasilproyeksi-penduduk-menurut-provinsi-2015--2035.html. Persentase Penduduk Daerah Perkotaan menurut Provinsi, 2010-2035. Badan Pusat Statistik. diunduh tanggal $30 \mathrm{Mei}$ 2021.

https://www.bps.go.id/website/materi_ind/materiBr sInd-20210215114827.pdf. Berita Resmi Statistika 15 Februari 2021. Badan Pusat Statistik. diunduh tanggal 30 Mei 2021.

http://induk-kud.com/kud-dinilai-sudah-saatnyaberganti-kemasan/. KUD Dinilai Sudah Saatnya Berganti Kemasan. Induk Koperasi Unit Desa. diunduh Tanggal 30 Mei 2021.

Mulyana, Deddy, 2001. Ilmu Komunikasi Suatu Pengantar. Bandung : Remaja Rosda Karya. 
278 Coopetition, Vol XII, Nomor 2, Juli 2021

(E-ISSN : 2615-4978, P-ISSN : 2086-4620)

Nur Arovah, Eva. 2003. Pesantren dan Pasar Perdesaan Cirebon. Agama dan Ekonomi di Tegalgubug Pada Abad XX. Thesis PS Sejarah. Yogyakarta: Universitas Gadjah Mada 